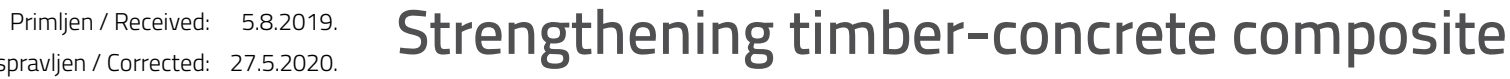 Prituaten/Accepted. 26.72020. girders with prestressed reinforcement
}

Authors:

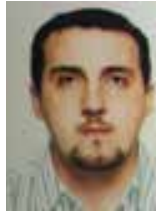

${ }^{1}$ Emir Maslak, MCE

e_maslak@yahoo.com

Corresponding author

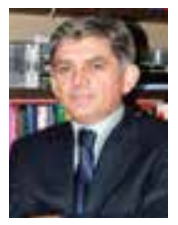

${ }^{1}$ Prof. Dragoslav Stojić, PhD. CE

dragoslav.stojic@gmail.com

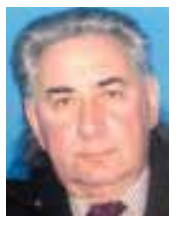

${ }^{1}$ Prof. Dragoljub Drenić, PhD. CE ddrenic@gaf.ni.ac.rs

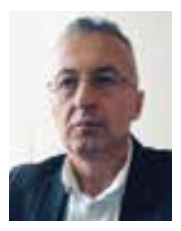

${ }^{2}$ Prof. Esad Mešić, PhD. CE esad_mesic@yahoo.com

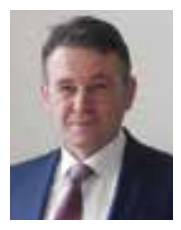

${ }^{1}$ Assist.Prof. Radovan Cvetković, PhD. CE radovancvetkovic@yahoo.com

University of Niš, Faculty of Civil Engineering and Architecture, Serbia

${ }^{2}$ University of Sarajevo, Faculty of Civil Engineering,

Bosnia and Herzegovina

\author{
Emir Maslak, Dragoslav Stojić, Dragoljub Drenić, Esad Mešić, Radovan Cvetković
}

\section{Strengthening timber-concrete composite girders with prestressed reinforcement}

Timber-concrete composite girders are a modern type of structure. They are formed by composite connection of a timber and concrete girder. They are designed in such a way that the concrete part of the girder is placed in the compression zone and the timber part of the girder in the tension zone. Various types of shear connectors are used for establishing this connection: from mechanical ones (bolts, nails, perforated plates, parts of steel sections, etc.) to chemical ones (various types of glue). The possibility of active strengthening of such girders with prestressed reinforcement is investigated in this paper. One possibility of applying external prestressing force is presented. Some strengthened-girder test results are presented and compared with results for similar girders but without strengthening.

Key words:

composite girders, timber-concrete, shear connectors, active strengthening, external reinforcement, prestressing

Prethodno priopćenje

Emir Maslak, Dragoslav Stojić, Dragoljub Drenić, Esad Mešić, Radovan Cvetković

\section{Ojačanje spregnutih nosača drvo-beton prednapetom armaturom}

Spregnuti nosači drvo-beton vrsta su suvremenih konstrukcija. Nastaju sprezanjem drvenoga i betonskog nosača. Projektiraju se tako da se betonski dio nosača postavlja u tlačnoj, a dio nosača od drveta u vlačnoj zoni. Za sprezanje se mogu upotrijebiti različite vrste moždanika, od mehaničkih (vijci, čavli, perforirane ploče, dijelovi čeličnih profila i dr.), do kemijskih (razne vrste lijepila). U radu je ispitana mogućnost aktivnoga ojačanja takvoga nosača prednapetom armaturom. Prikazan je jedan od načina unošenja vanjske sile prednapinjanja. Priloženi su određeni rezultati ispitivanja ojačanih nosača i upoređeni s istim takvim nosačima, ali bez ojačanja.

Ključne riječi:

spregnuti nosači, drvo-beton, moždanici, aktivno ojačanje, vanjska armatura, prednapinjanje

Vorherige Mitteilung

Emir Maslak, Dragoslav Stojić, Dragoljub Drenić, Esad Mešić, Radovan Cvetković

\section{Bewehrung von Holz-Beton-Verbundträgern mit vorgespannter Bewehrung}

Holz-Beton-Verbundträger sind eine Art moderne Konstruktion. Sie werden durch Kopplung eines Holz- und eines Betonträgers gebildet. Sie sind so ausgelegt, dass der Betonteil des Trägers in der Druckzone und ein Teil des Holzträgers in der Zugzone angeordnet ist. Zum Koppeln können verschiedene Arten von Verbindern verwendet werden, von mechanischen (Schrauben, Nägel, Lochplatten, Teile von Stahlprofilen usw.) bis hin zu chemischen (verschiedene Arten von Klebstoffen). In der Arbeit wurde die Möglichkeit einer aktiven Bewehrung eines solchen Trägers mit vorgespannter Bewehrung untersucht. Es wird eine Möglichkeit zum Einbringen der externen Vorspannkraft gezeigt. Bestimmte Testergebnisse von bewehrten Trägern sind beigefügt und werden mit denselben Trägern verglichen, jedoch ohne Bewehrung.

Schlüsselwörter:

Verbundträger, Holz-Beton, Dübel, aktive Bewehrung, Außenbewehrung, Vorspannung 


\section{Introduction}

Timber-concrete composite girders initially stemmed from the need to renovate the existing old timber floor structures in times after big wars, when steel was scarce. By placing a concrete slab over timber girders that were previously fitted with mechanical connectors (nails, bolts, pieces of steel sections, etc.) a new form of girder was created that had not only a higher load bearing capacity, but also a number of other significant advantages:

- it is easier to placeabove the subsequently placed concrete layer the layers that improve sound insulation, thermal insulation, and waterproofing capacity of the structure,

- the reinforced-concrete slab stiffness is sufficient to balance horizontal displacements at the floor structure level, which greatly improves dynamic properties of the overall structure,

- increased fire resistance of the structure,

- positive influence on the interior due to "sensation of warmth" and beautiful appearance of the timber part of the girder in cases when it remains visible within the structure.

The above advantages show that, in addition to better static and dynamic properties and a relatively easy assembly, this composite structure enables significant improvement of parameters related to the functionality of the structure/ building. Thanks to such favourable properties of composite girders, they have been increasingly used not only as a solution during renovation and strengthening of existing structures, but also during the design of new ones. The development of technology that has enabled realization of glued laminated girders has eliminated limitations as to span and shape of cross section, which existed in the case of girders made of solid wood, so that today it is possible to design such girders for bridging considerable spans. In building construction, depending on the building's occupancy, such girders can be used for spans of up to $10.0 \mathrm{~m}$ or more in length, while in bridge construction the spans of $30.0-40.0$ are considered as cost-effective (Evenstad Bridge $5 \times 36.0 \mathrm{~m}$, Vihantaslami Bridge $21.0+3 \times 42.0+21.0 \mathrm{~m}$ ).

On the other hand, in the case of prestressed girders, deformations are caused already at the assembly stage in some elements (or in the entire structure) so that a more favourable behaviour can be obtained during the service life of the facility. The advantage of such girders can best be seen in the fact that designers take a more active part in the redistribution of stress and strain compared to the situation with traditional girders.

\section{Prestressed timber-concrete girders}

As a consequence of an increase in the use of such girders in civil engineering, the need arose to study more thoroughly their behaviour in real-life structures. The implementation of such structural system was registered during strengthening of the timber floor structure of the Good Shepherd Building in Bratislava in 1960 [1]. The cross section of the strengthened girder is shown in Figure 1.
Four rows of nails were installed in the existing timber beams, and a concrete slab $6.0 \mathrm{~cm}$ in thickness was placed on top. The testing of these girders revealed that their stiffness and bearing capacity increased by approximately 4 times.

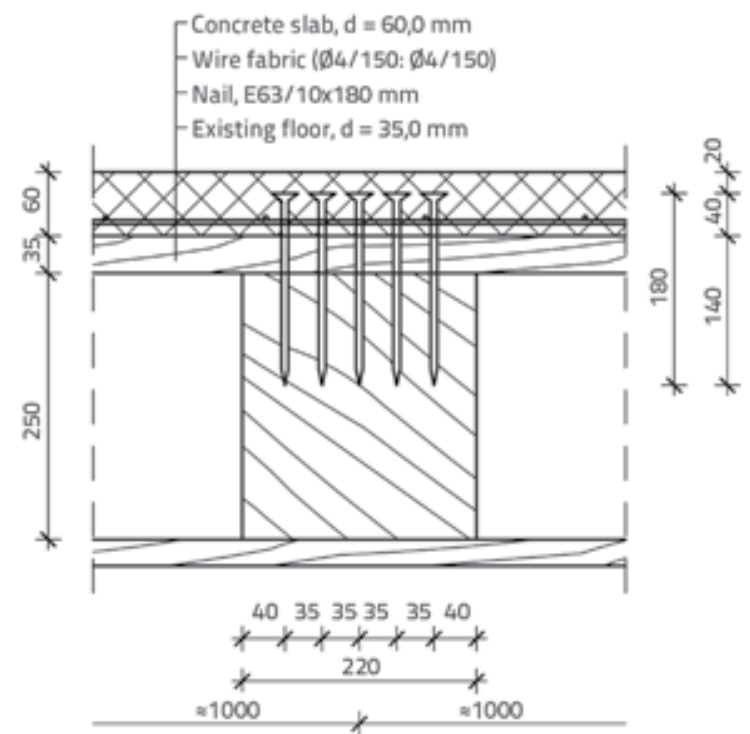

Figure 1. Cross section of composite girder of the Good Shepherd Building [1] (dimensions are in $\mathrm{mm}$ )

A considerable number of theoretical and experimental investigations have been conducted since that time, and these investigations have offered numerous answers to designers, and provided them with the possibility of designing such structures in various ambient settings. The behaviour of such girders under load is determined by a number of factors. In addition to geometrical and mechanical characteristics of structural elements, the greatest influence is exhibited by the stiffness of connections that are used to ensure composite action. The connection between the timber and concrete girder can be established in a number of ways. The most frequently used connections are mechanical ones that connect the two elements at appropriate points (nails, bolts, pieces of reinforcing bars). These connectors can be installed either as vertical or inclined members. The link can also be established by cutting notches into the timber part of the girder, and by filling such notches with concrete during concrete placing. In addition to these connections, the use is also made of shear connectors enabling establishment of a continuous connection - toothed slabs, perforated or smooth slabs with curved top, etc. In recent times, thanks to technological advancements, glues have been used for ensuring full composite action of these girders. Generally, connections can be classified [2] according to material they are made of (metal, wood), according to installation along the beam (discrete/continuous, vertical/inclined), and according to the way they are installed in the timber part of the girder (glued/not-glued, prestressed/non-prestressed). The type of shear connector defines the efficiency of composite action that will be achieved, i.e. the shear connector type defines the girder's response to external load. Classification of shear connections as a function of 
stiffness and efficiency of composite action achieved is given in [3]. According to this classification, all connectors are classified into four categories ( $A, B, C$, and $D)$, where connectors exhibiting the lowest strength and ductility belong to category one (A), while connectors that are capable of ensuring almost full composite action belong to the last category (D). The behaviour of connectors is most often defined through the sliding modulus. The most reliable way of obtaining this information is by experiment (using the so called push out test). Extensive research on the determination of this parameter for various connector types can be found in [4]. The results are presented in form of comparative diagrams (Figure 2) where forcedisplacement curves of tested samples can be seen.

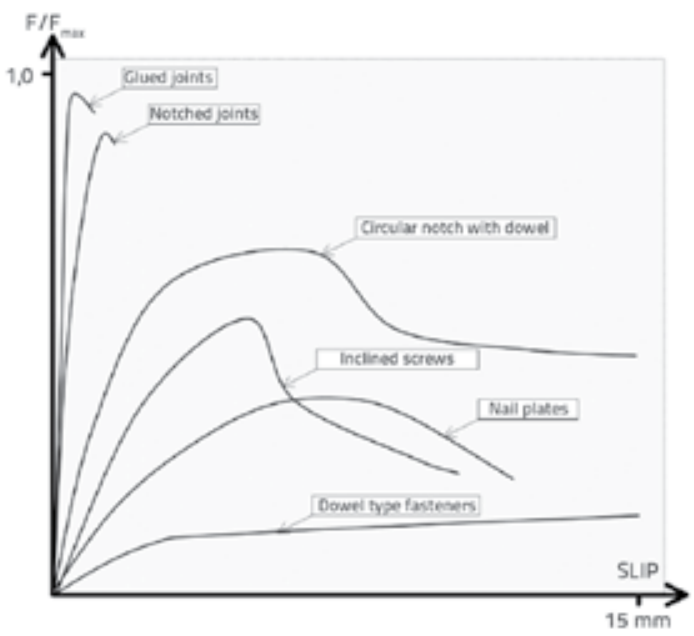

Figure 2. Sliding modules for various connector types [4]

This figure clearly shows that, from the standpoint of bearing capacity, the most favourable properties during connection of these two girders are exhibited by glued connections, while the least favourable properties are attributed to connections realised by bolts. The influence of mechanical characteristics of concrete part of a composite girder was tested in [5], where concrete with the volumetric weight of $1,60 \mathrm{kN} / \mathrm{m}^{3}$ was used in order to reduce permanent load on the girder. It was concluded that this type of concrete has a considerable influence on the effective flexural stiffness of the entire structure and that, consequently, in such cases the connectors had to be more densely spaced compared to composites with concrete exhibiting normal volumetric weight.

Many tests have been conducted on real girders in order to estimate the bearing capacity and failure mechanisms. Especially valuable are the tests that were conducted on girders which were first exposed to longterm load and then tested to failure by shortterm load. Such testing enables monitoring of the way in which behaviour of structures is affected by rheological parameters. One such testing is presented in [6]. The beams were uniformly loaded to $4.0 \mathrm{kN} / \mathrm{m}$ during five years and, during that time, the following parameters were monitored: ambient conditions (temperature, relative air humidity), moisture in wooden part of the girder, global deformations (deflection at the centre of the girder, relative beam displacements above the bearings) and local deformations (dilation parallel and perpendicular to fibres in the centre of the girder). This was followed by testing involving short-time load. In the preparation phase, the beams were subjected to load in elastic area so as to determine position of neutral axis, and then the testing was continued until failure. Some parts of the girder were cut out of tested beams in order to perform the push-out test and determine the sliding modulus. Based on test results, the deformation after fifty years was estimated and the results obtained experimentally and analytically were compared for various classes of use and for various connection sliding moduli. Concrete shrinkage, as an inevitable part of the hardening process, is one of disadvantages during realisation of such girders by wet procedure. The research conducted in [7] was aimed at testing possibility of connecting the completed concrete slab with the timber girder using the dry procedure. The tests were conducted under static load (short-term and long-term) and dynamic load. The beams tested in the scope of this research measured $4.80 \mathrm{~m}$ in span and were characterised by triple T cross section. Two composite system types were applied. The first system involved specially formed $U$ upper part that was previously installed in the concrete slab, while the second part was fixed to the wooden beam by nails. The second system involved bolts $20.0 \mathrm{~mm}$ in diameter that were fixed to the completed concrete slab via metal bushings previously installed in the slab. The efficiency of composite action achieved on the tested beams was not satisfactory, i.e. it amounted to $31 \%$ and $57 \%$ for the first and second system, respectively. Numerical investigations conducted in this research give preference to the second composite system in combination with notches, as this can greatly increase the efficiency of composite connection.

\subsection{Theory of elastic composite connection}

Three typical cases can occur during connection of concrete slab and timber beam, cf. Figure 3.
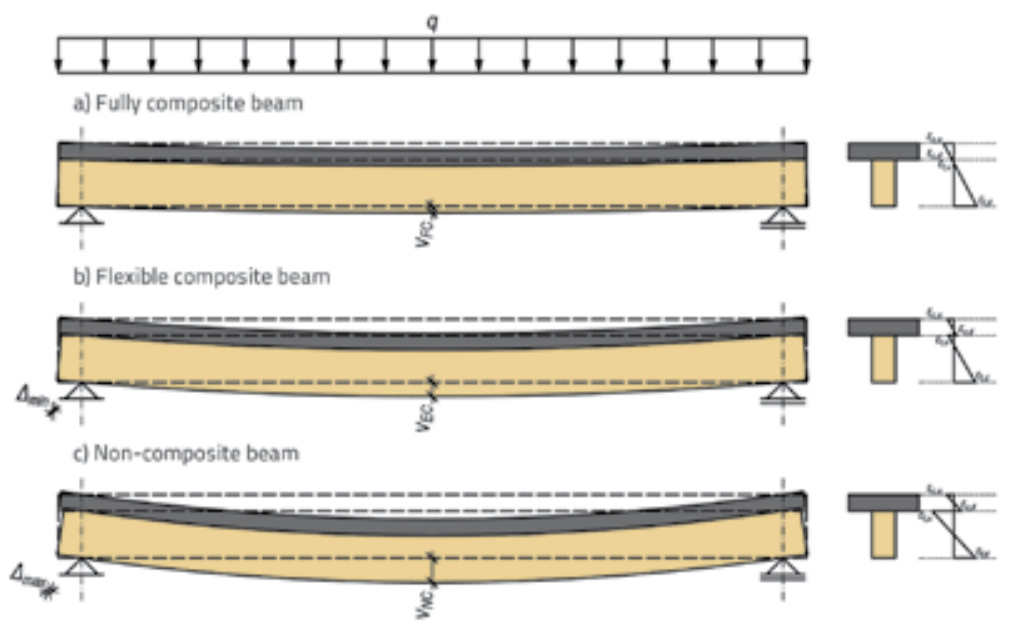

Figure 3. Girder deformation as related to efficiency of composite connection 
Behaviour of composite girder under load will depend of the efficiency of composite connection. According to [8], this parameter can be calculated according to expression (1):

$E=\frac{\Delta_{N C}-\Delta_{P C}}{\Delta_{N C}-\Delta_{F C}}$

where $\Delta_{N C} \Delta_{P C}$ and $\Delta_{F C}$ are deflection of non-composite girder, partial (elastic) deflection of composite girder, and full (stiff) deflection of composite girder, respectively.

The deformation and dilation of a fully composite beam is shown in Figure 3.a. In such beams, there are theoretically no relative displacements in the contact plane, but rather the connectors are sufficiently stiff to fully assume shear stress. The dilation diagram has one neutral axis and the value of dilations is the same in the connection plane. A continuous connector or glue must be used for realisation of such girders. The coefficient of composite efficiency for this type of girder is $\mathrm{E} \rightarrow 1$.

On the other hand, the case of non-composite beam is shown in Figure 3.c. In the case of this girder the dilation diagram has two neutral axes and, in the case of bending without longitudinal force, these neutral axes are situated in the centres of gravity of individual girders. The connector stiffness value at the contact between the concrete and timber girder is negligible and, therefore, relative displacements between individual girder elements assume maximum values. For this type of girder, the coefficient of composite efficiency is $\mathrm{E} \rightarrow 0$.

Timber-concrete composite girders cover the range between the two previous boundary cases (Figure 3.b.). The diagram of dilations for the most frequently used connectors has two neutral axes that are spaced, depending on their stiffness values, at mach smaller intervals compared to the case registered for the third girder. Relative displacements between elements do exist, but are smaller compared to non-composite girder.

In the case of the first girder, the calculation, based on elastic theory, involves calculation of geometric properties of an idealised cross section and calculation, for such an idealised cross section, of longitudinal stress and strain in boundary fibres of constitutive elements. As to the third girder type, which is the least often used in engineering practice, the procedure involves calculation of stiffness of individual girder elements and, depending on stiffness of individual elements, redistribution of internal forces: moment - proportionally to flexural stiffness El, possibly longitudinal force - proportionally to axial stiffness EA, while the greatest part of transverse force is assumed by timber girder. In the case of the girder shown in Figure 3.b., the expressions describing state of stress and strain under an arbitrary load are much more complex, which is due to the yieldable nature of connectors. The analytical solution for composite beam with yieldable shear connectors, developed by means of the differential equation of equilibrium, can be found in $[9,10]$. The following assumptions are introduced when shaping the equation system:

- linear elastic behaviour of material and connector

- assumption on small displacements (first order theory)

- at deformation, the RC slab and timber beam have the same inclinations of elastic lines

- Bernoulli hypothesis on flat cross sections is applicable

- it is assumed that connectors are uniformly (continuously) distributed along the connection

- cross sections are constant along the longitudinal axis of the girder.

Equilibrium equations of a differentially small part of the girder shown in figure 4 were set for the mentioned conditions.

Analytical solution to this problem is reduced to the nonhomogeneous differential equation of the fourth order with constant coefficients, the form of which is given by equation (2):

$w^{\prime v}(x)-\alpha^{2} \cdot w^{\prime \prime}(x)=\alpha^{2} \cdot \frac{M(x)}{E I_{\infty}}+\frac{q(x)}{E I_{0}}$

where:

$\alpha^{2}=k \cdot\left(\frac{1}{E A_{1}}+\frac{1}{E A_{2}}+\frac{a^{2}}{E I_{0}}\right)$

$E I_{0}=E_{1} I_{1}+E_{2} I_{2}$

$E I_{\infty}=E I_{0}+\frac{E_{1} A_{1} \cdot E_{2} A_{2}}{E_{1} A_{1}+E_{2} A_{2}} \cdot a^{2}$

Flexural stiffness of a non-composite beam is defined in equation (4), while flexural stiffness of a fully composite cross section is given in equation (5). The solution describes behaviour of these girders under load fairly well, although there are some deficiencies. The first deficiency is that the closed form solution is difficult to find for slightly more complex constellations of load. The second deficiency is that these phenomena are not covered by this solution as both timber and concrete are rheological materials. The dimensioning of multi-part girders of constant cross section, connected by mechanical connectors, is defined in Annex B of Eurocode 5 [12]. This procedure relies on the theory of elastic composite action, albeit 
with some simplifications. To obtain a closed form solution, it is assumed that the load acts in the form of sine function. In literature, this calculation method is known as the $\gamma$-procedure and involves calculation of effective flexural stiffness of an elastically linked composite cross section. That expression includes all parameters that are significant for the redistribution of force within the girder cross section: mechanical properties (elastic modulus of the timber and concrete part of cross section), geometrical properties (area, moments of inertia) and yieldable nature of connection at the girder contact level (sliding modulus). The effective flexural stiffness is calculated according to equation (6):

$(E I)_{\text {eff }}=\sum_{i=1}^{n} E_{i} l_{i}+\gamma_{i} E_{i} A_{i} a_{i}^{2}$

As in this case the cross section is composed of two elements, the parameter $i$ that occurs in equation (6) will amount to 2 . Other factions in equations (6) are:

- elastic modulus of timber and concrete, $\mathrm{E}$

- moments of inertia of timber and concrete, $I_{i}=\frac{b_{i} \cdot h_{i}^{3}}{12}$

- areas of cross sections, $A_{i}=b_{i} \cdot h_{i}$

$-\gamma_{2}=1$

$-V_{1}=\left[1+\frac{\pi^{2} \cdot E_{1} A_{1} \cdot s_{1}}{K_{i} \cdot l^{2}}\right]^{-1}$

In addition to elastic modulus and area, the following members occur in equation (9):

- equivalent spacing of connectors $\left(s_{1}\right)$ used in composite connections; if they are not spaced at similar intervals, they can be calculated as follows:

$s_{e q}=0.75 \cdot s_{\min }+0.25 \cdot s_{\max }$

- sliding modulus of connections used in the contact plane of composite girder $\left(K_{1}\right)$; it is obtained either experimentally or according to recommendations [12]. According to proposal [13] it is assumed for sliding modulus values that:

$$
a_{1}=\frac{Y_{1} \cdot E_{1} A_{1} \cdot a}{Y_{1} \cdot E_{1} A_{1}+E_{2} A_{2}}
$$

It can be seen in Figure 3 that $a=\frac{h_{1}}{2}+\frac{h_{2}}{2}$, i.e. that $a_{2}=a-a_{1}$.

Redistribution of internal forces and stresses along elements is defined (Figure 5):

a) for RC slab:

$N_{1}=\frac{M_{E d}}{(E I)_{\text {eff }}} \gamma_{1} \cdot a_{1} \cdot E_{1} \cdot A_{1}$, and hence $\sigma_{n, 1}=\frac{N_{1}}{A_{1}}$

$M_{1}=\frac{M_{E d}}{(E I)_{\text {eff }}} E_{1} \cdot l_{1}$ and hence $\sigma_{m, 1}= \pm \frac{M_{1}}{l_{1}} \cdot \frac{h_{1}}{2}$

and, finally $\sigma_{c, \max }=\sigma_{n, 1}+\sigma_{m, 1}$ provided that $\frac{\sigma_{c, \max }}{f_{c, d}} \leq 1$

b) for timber beam:

$N_{2}=\frac{M_{E d}}{(E I)_{\text {eff }}} Y_{2} \cdot a_{2} \cdot E_{2} \cdot A_{2}$ and hence $\sigma_{n, 2}=\frac{N_{2}}{A_{2}}$

$M_{2}=\frac{M_{E d}}{(E I)_{\text {eff }}} E_{2} \cdot I_{2}$, and hence $\sigma_{m, 2}= \pm \frac{M_{2}}{I_{2}} \cdot \frac{h_{2}}{2}$

and, finally $\sigma_{t, \max }=\sigma_{n, 2}+\sigma_{m, 2^{\prime}}$ provided that $\frac{\sigma_{n, 2}}{f_{t, 0, d}}+\frac{\sigma_{m, 2}}{f_{m, d}} \leq 1$

Verification of shear stresses:

Under assumption that the full transverse force is assumed by the timber beam:

$T_{2}=\frac{0.50 \cdot V_{E d} \cdot E_{2} \cdot h_{2}^{2}}{(E I)_{\text {eff }}}$, provided that, $\frac{T_{2}}{f_{v, d}} \leq 1$

where $M_{E d}$ and $V_{E d}$ are limit values of influence, obtained through appropriate partial safety factors.

For verification according to the serviceability limit state, it is necessary to calculate the effective flexural stiffness using the sliding modulus $K_{\text {ser }}$. The sliding modulus calculated in this way is used to determine the girder deflection for the case of the uniformly distributed load:

$v_{\text {max }}=\frac{5}{384} \cdot \frac{q \cdot l^{4}}{(E I)_{\text {eff,ser }}}$, provided that $v_{\text {max }} \leq v_{\text {dop }}$

$K_{\text {ser }}=\frac{0.40 R_{m}}{v_{040}}, K_{u}=\frac{0.60 R_{m}}{v_{060}}$ or $K_{u}=\frac{2}{3} K_{\text {ser. }}$

As already indicated, both concrete and

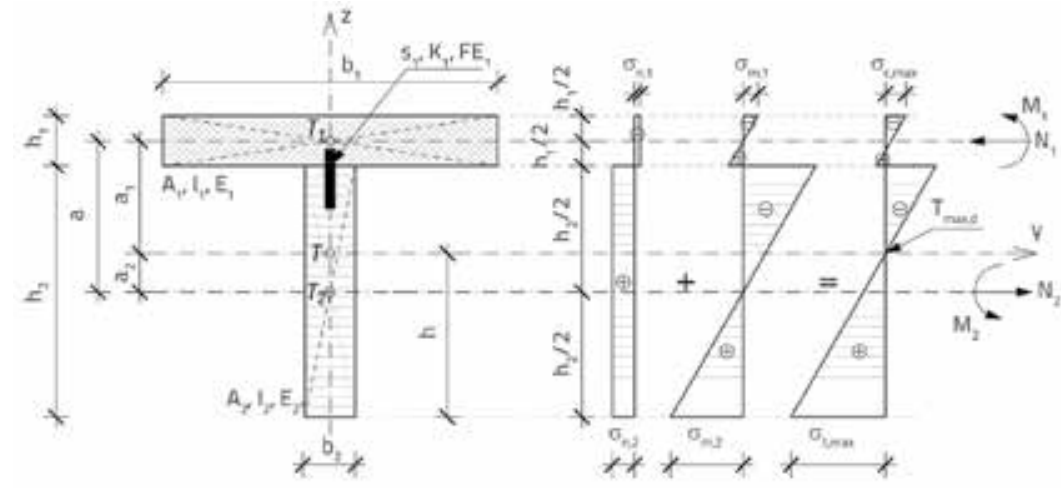
timber are rheological materials, which means that they are susceptible to the change of mechanical properties over time. These changes are influenced by various factors, the most significant being: duration of load, air humidity, temperature, etc. In order to take into account these phenomena at least to some extent, the load bearing capacity of such girders is proven in two stages. In the first stage, the load bearing capacity is checked for

Figure 5. Stresses in elastically connected composite girder 
short-term load with mechanical properties of materials that are obtained according to the already described procedures. The second stage involves verification of bearing capacity of girders with long-term effects. The application of this calculation method, with a numerical example, can be found in [14].

\section{Strengthening of timber-concrete composite girders}

Strengthening procedures for various types of structures have so far been studied quite extensively and the corresponding results are available to a wide circle of engineers. The use of materials with advanced mechanical properties, such as carbon fibres, has greatly facilitated the use of such procedures. The technology for their relatively easy application has been developed and, in addition, they increase the dimensions of load bearing elements only slightly, and are not susceptible to corrosion. The issue of composite girder strengthening has so far been studied by a small number of researchers. The possibility of strengthening composite girders using carbon fibres (CRFR - carbon fibre reinforced polymers) is presented in [15], where a bearing capacity calculation proposal compliant with recommendations given in [14] is also given. The girders are strengthened in such a way that carbon fibres are placed at the bottom tensile edge of the timber beam, as shown in Figure 6 . The strengthening of tensile zone of the timber beam not only results in global increase in bearing capacity, but also in an increase in girder ductility, because brittle fracture occurs at tensile fibres in timber girders. A deficiency of this procedure is that the testing conducted on timber girders strengthened in the described way has pointed to the timber girder delamination problem. In fact, delamination greatly precedes achievement of bearing capacity of carbon fibres.

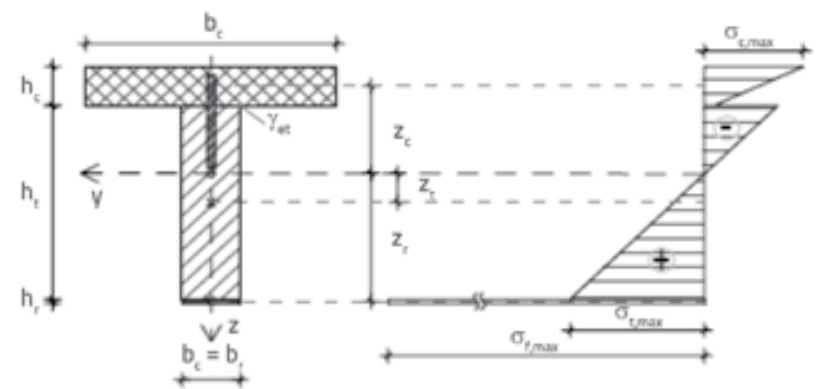

Figure 6. Model of girder reinforced with CFRP fibres [15]
The possibility of strengthening girders formed by composite connection of veneer elements (LVL girders) and concrete is presented in [16]. Three types of girders $6.0 \mathrm{~m}$ in span were tested. The first type involved composite beams, one of which was made by "wet" procedure using normal weight concrete, and the other using the reduced weight concrete that was cast separately, and then connected with timber beam at the place of assembly. The other type involved beams formed by prestressing using external reinforcement. In one beam, the reinforcement runs polygonal with two deviators, and the anchoring is done in the concrete slab, while in the other, the reinforcement runs rectilinear, and the anchoring is done in the timber beam. The appearance of prestressed girders, and cross-sectional shape and dimensions, are given in Figure 7. In addition to the difference in cross section and the way in which the prestressing force is applied, different composite systems were also used. Thus, a stiffer composite system was applied in the case of the prestressed girder with polygonal spreading, while a more flexible system was used for the girder with rectilinear spreading. One sample was tested for each girder type. Dynamic properties of girders were determined prior to static testing until failure.

Unlike the previous option, this paper focuses on the possibility of strengthening composite girder by reinforcement that is situated outside of its cross section. In order to obtain reliable results, as many as ten composite girders were tested, out of which five were only made composite, while the other five were made composite and prestressed.

Aspecial problem encountered when dimensioning this type of girder was the way in which the prestressing force should be introduced, because it was necessary to avoid at the same time the effects of relaxation of links for reinforcement anchoring. The system accepted for testing is composed of a connecting steel element which is, at the end of the girder, shaped as a box (Figure 8).
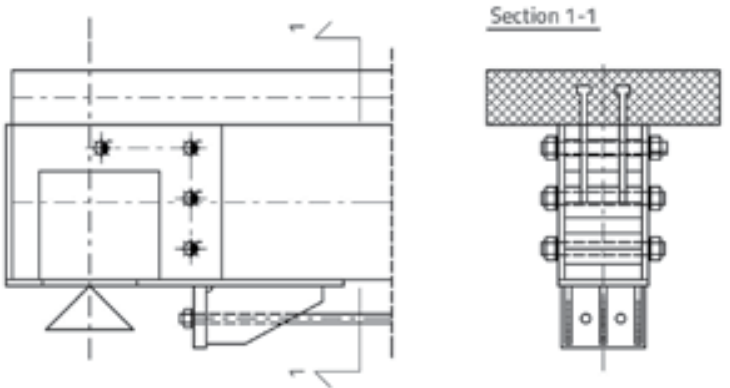

Figure 8. Structure for introduction of prestressing force
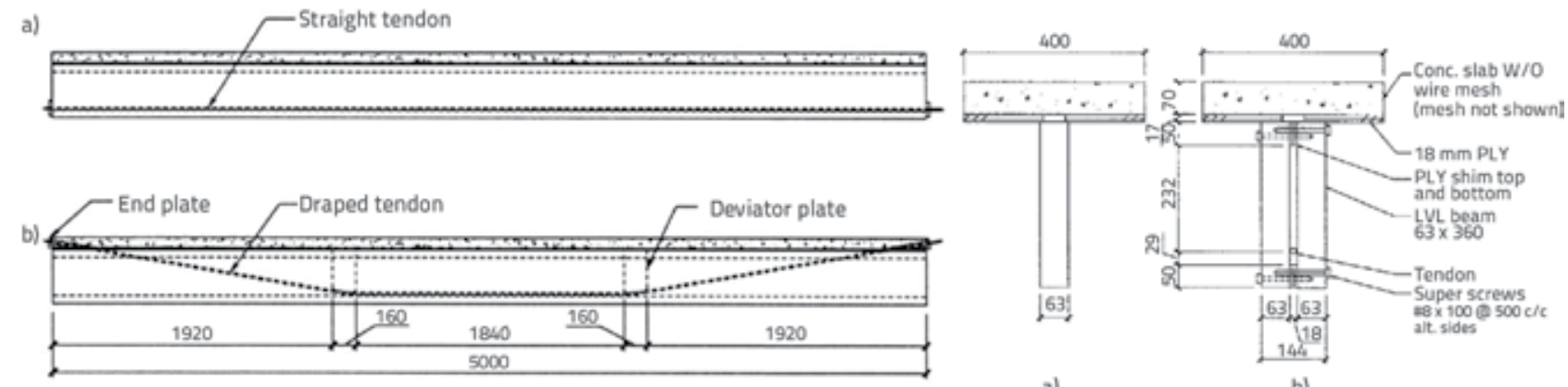

a)

b)

Figure 7. Appearance and dimensions of tested girders (dimensions are in mm) [16] 
The advantage of this prestressing force introduction system lies in the simplicity of its application. It can be seen in figures 8 and 11 that the spreading of external reinforcement is rectilinear, and so the prestressing force is introduced using a simple spanner or impact spanner. This advantage also implies the possibility of subsequent increase of force in reinforcement, as the force is bound to decrease both in the prestressing phase, and during service life of the structure. The compression component of the force, which occurs as a consequence of eccentric introduction of force into the girder, is transferred by the frontal plate of the timber beam, while the tension component is mostly transferred by bolts.

An analysis using the finite element method was conducted in order to determine the state of stress at the point where the prestressing force is introduced into the girder prior to the testing itself. The modelling involved only the wooden part of the girder with steel part onto which the force

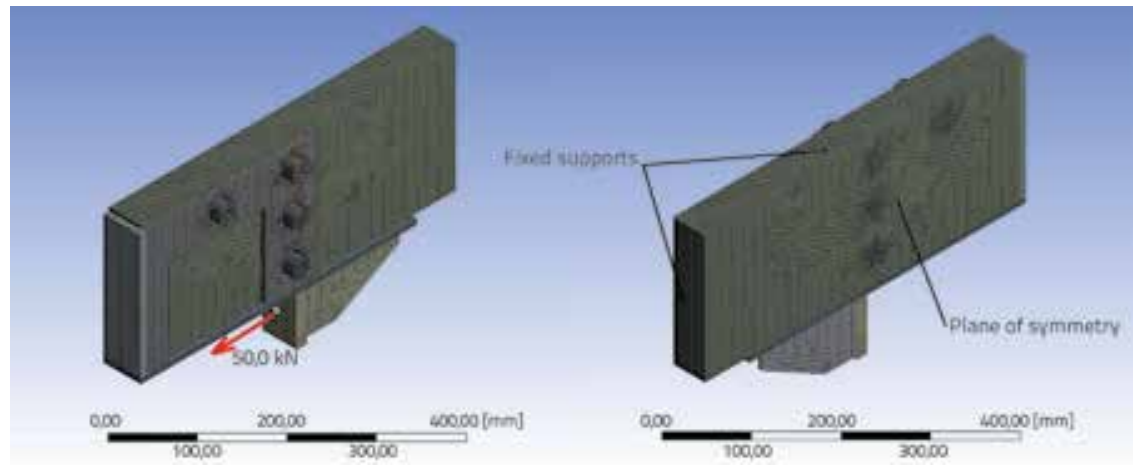

Figure 9. Numerical model of the element for introducing the prestressing force

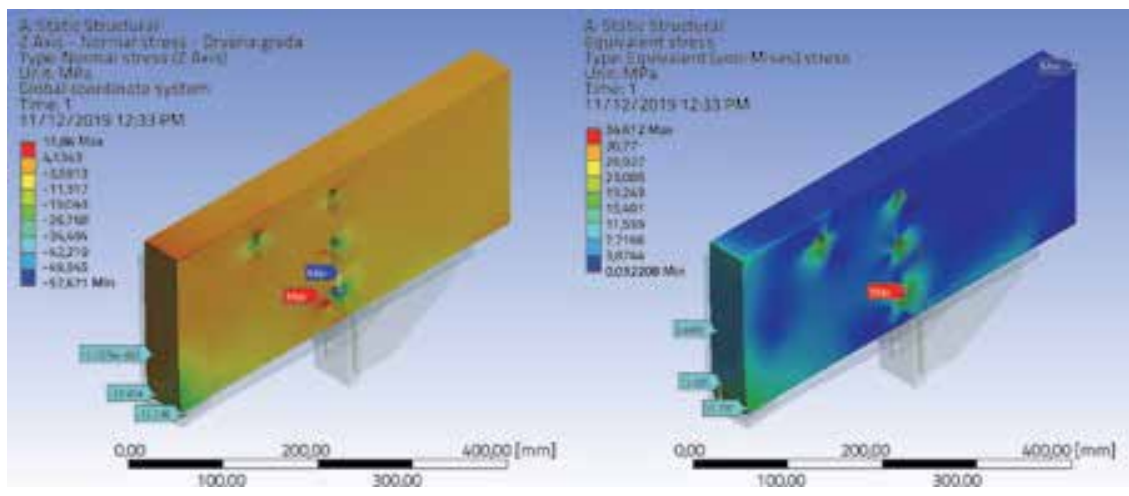

Figure 10 Results in timber part of the girder obtained by finite element method

of $50.0 \mathrm{kN}$ was applied, as this was the expected force in one tendon. The part of the girder that was modelled is presented with real geometry by means of SOLID elements. Connections (timber girder - steal shoe, timber girder bolts, and steel shoe - bolts) were modelled via the CONTACT and TARGET finite elements, while the influence of friction was neglected. A special problem in numerical analysis of these girders involves material model of timber due to its pronounced anisotropy. A more complex material model that would include anisotropy and post-elastic behaviour of timber was not applied in the preliminary analysis that was conducted on the model. Instead, an isotropic model in linear area, with the modulus of elasticity of $1100.0 \mathrm{kN} /$ $\mathrm{cm}^{2}$ was accepted. In order to shorten calculation time, the symmetry property was used when modelling this part of the structure, and so one of its halves was analysed. The numerical model with generated network of finite elements is presented in Figure 9.

Calculation results are shown in Figure 10 where longitudinal stresses on the girder axis line, and the equivalent (vonMises) stresses, are shown. Longitudinal stresses are shown so that they can be qualitatively estimated in the frontal part of timber beam, and thus to gain insight into the type of stress (compression or tension). The obtained results are highly compliant with expectations.

\section{Experimental analysis of girders}

Experimental analysis of the girders under study was preceded by a detailed nonlinear numerical analysis based on the finite element method (ANSYS Workbench 16.2.). The study of girder behaviour has enabled determination of parameters that served as basis for shaping the tested model.

The experimental testing was conducted in the Laboratory of the Institute for Materials and Structures operating within the Faculty of Civil Engineering of the University of Sarajevo. The behaviour of five composite and five composite-prestressed beams was tested according to the test setup presented in Figure 11. Bolts without nuts (M8×150.0 mm), arranged in two rows, were used as shear connectors. The same arrangement of measurement points on the composite beam was used for common elements (timber beam and concrete slab).

The prestressing force value was determined on the unloaded girder based on condition that stress approximately equal to the tensile strength of concrete $\left(0.25 \mathrm{kN} / \mathrm{cm}^{2}\right)$ occurs at boundary fibres of the concrete girder. This means that expected dilations in measurement strips $\mathrm{GC}_{3}$ and $\mathrm{GC}_{4}$ (Figure 11) should be:

$\varepsilon_{1}^{u} \approx \frac{\sigma_{c}}{E_{c}} \approx \frac{0.25}{3100.0} \approx 0.806 \% \approx 80.645 \mu D$.

Girders prepared for testing are shown in Figure 12. 


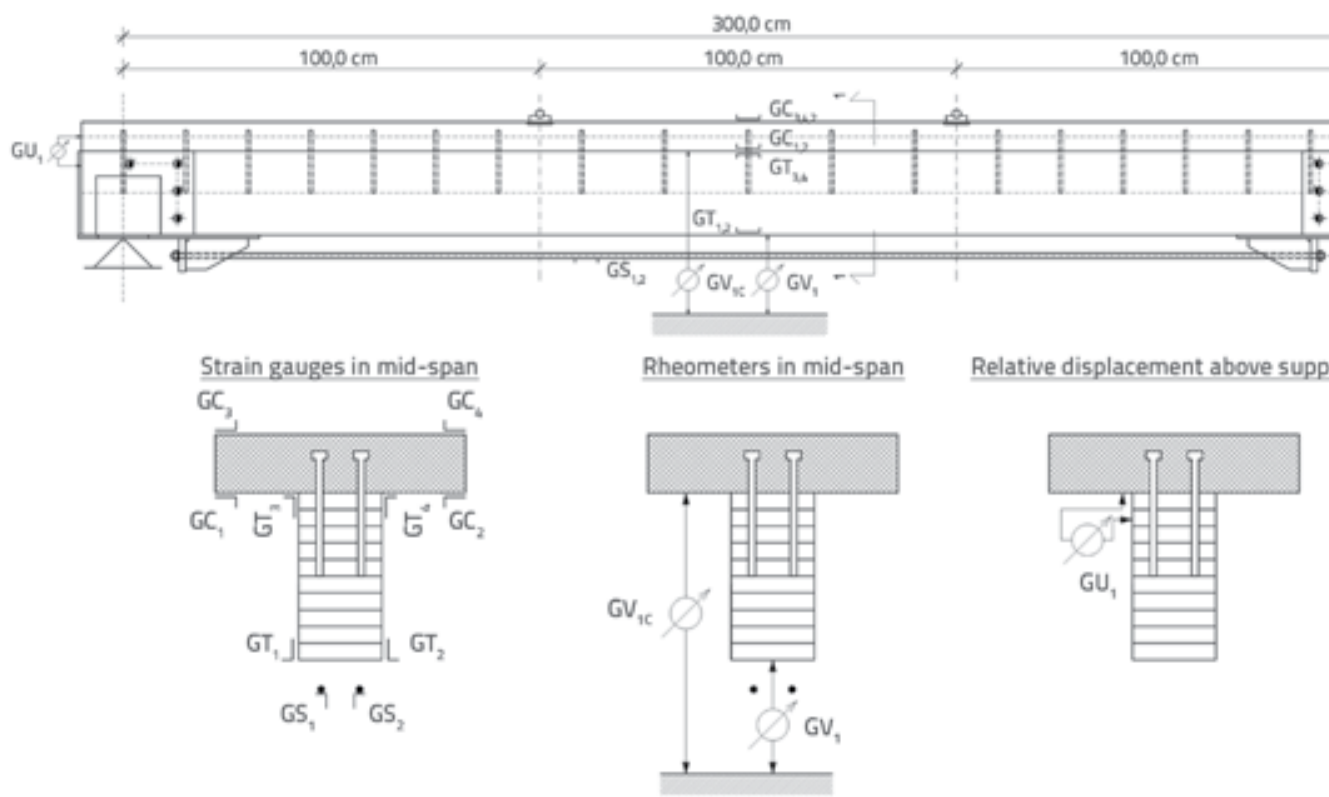

Figure 11. Test setup for testing strengthened girder, with the disposition of measurement points (dimensions are in cm)

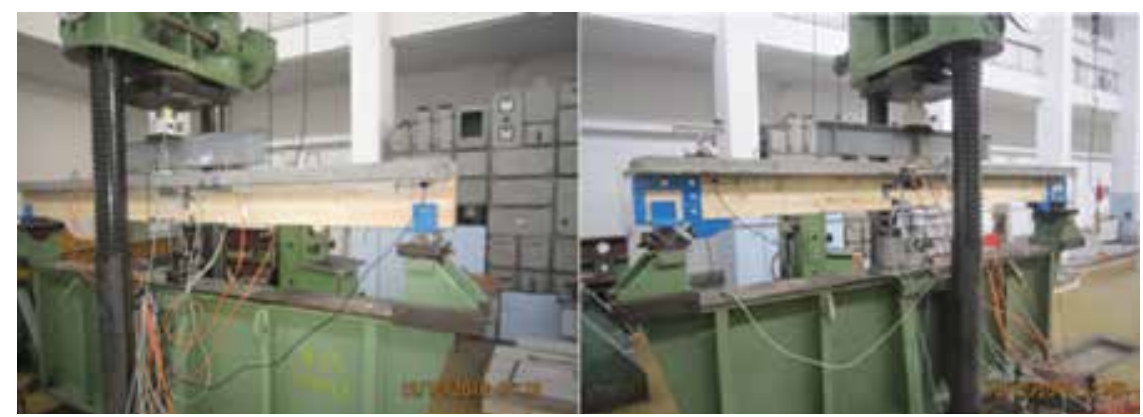

Figure 12. Girders prepared for testing
The force was applied on girders by means of a hydraulic jack through an intermediary of a rigid steel girder, as recommended in EN 26891 [12], using the SPIDER 8 multi-channel measurement system. The load was increased in $5.0 \mathrm{kN}$ increments until failure. Measurement point designations, measurement values, and instruments used in measurements are given in Table 1.

Table 1. Designation of measurement points on tested beams

\begin{tabular}{|c|c|c|c|c|c|c|c|c|c|c|c|c|c|c|c|}
\hline \multicolumn{16}{|c|}{ Composite-prestressed girders (five units) } \\
\hline $\begin{array}{l}\text { Measurement } \\
\text { point }\end{array}$ & $\mathrm{G}_{\mathrm{i}} \mathrm{S}_{1}$ & $\mathrm{G}_{\mathrm{i}} \mathrm{S}_{2}$ & $\mathrm{G}_{\mathrm{i}} \mathrm{T}_{1}$ & $\mathrm{G}_{\mathrm{i}} \mathrm{T}_{2}$ & $\mathrm{G}_{\mathrm{i}} \mathrm{T}_{3}$ & $\mathrm{G}_{\mathrm{i}} \mathrm{T}_{4}$ & $\mathrm{G}_{i} \mathrm{C}_{1}$ & $\mathrm{G}_{1} \mathrm{C}_{2}$ & $\mathrm{G}_{i} \mathrm{C}_{3}$ & $\mathrm{G}_{1} \mathrm{C}_{4}$ & $\mathrm{G}_{\mathrm{i}} \mathrm{V}_{1}$ & $G_{i} V_{1 c}$ & $\mathrm{G}_{\mathrm{i}} \mathrm{U}_{1}$ & $\mathrm{G}_{\mathrm{i}} \mathrm{U}_{2}$ & D \\
\hline $\begin{array}{l}\text { Instrument } \\
\text { type }\end{array}$ & MT1 & MT1 & MT2 & MT2 & MT3 & MT3 & MT2 & MT2 & MT2 & MT2 & PM1 & PM2 & DM & $\mathrm{DM}$ & FM \\
\hline \multicolumn{16}{|c|}{ Composite girders (five units) } \\
\hline $\begin{array}{c}\text { Measurement } \\
\text { point }\end{array}$ & & & $\mathrm{G}_{\mathrm{i}} \mathrm{T}_{1}$ & $\mathrm{G}_{\mathrm{i}} \mathrm{T}_{2}$ & $\mathrm{Gi}_{3}$ & $\mathrm{G}_{\mathrm{i}} \mathrm{T}_{4}$ & $\mathrm{G}_{\mathrm{i}} \mathrm{C}_{1}$ & $\mathrm{G}_{1} \mathrm{C}_{2}$ & $\mathrm{G}_{\mathrm{i}} \mathrm{C}_{3}$ & $\mathrm{Gi}_{\mathrm{i}} \mathrm{C}_{4}$ & $\mathrm{G}_{\mathrm{i}} \mathrm{V}_{1}$ & $\mathrm{G}_{\mathrm{i}} \mathrm{V}_{1 c}$ & $\mathrm{G}_{\mathrm{i}} \mathrm{U}_{1}$ & $\mathrm{G}_{\mathrm{i}} \mathrm{U}_{2}$ & D \\
\hline $\begin{array}{l}\text { Instrument } \\
\text { type }\end{array}$ & & & MT2 & MT2 & MT3 & MT3 & MT2 & MT2 & MT2 & MT2 & PM1 & PM2 & DM & DM & FM \\
\hline $\begin{array}{l}\text { MT1 - strain g } \\
\text { MT2 - strain g } \\
\text { MT3 - strain g } \\
\text { PM1 - inducti } \\
\text { PM2 - inducti } \\
\text { DM - electror } \\
\text { FM - electror }\end{array}$ & $\begin{array}{l}\text { jes TML } \\
\text { jes TML } \\
\text { jes KYO। } \\
\text { isplacen } \\
\text { isplacen } \\
\text { deflecto } \\
\text { deflecto }\end{array}$ & $\begin{array}{l}\text { Tokyo So } \\
\text { Tokyo So } \\
\text { A, tip KF } \\
\text { ent conv } \\
\text { ent conv } \\
\text { leter } \\
\text { eter }\end{array}$ & $\begin{array}{l}\text { i Kenky } \\
\text { i Kenky } \\
-30-120 \\
\text { ter (LVD } \\
\text { ter (LVD }\end{array}$ & $\begin{array}{l}\text { Co., Lt } \\
\text { Co., Lt } \\
-1-11, \\
\text { - linear } \\
\text { - linear }\end{array}$ & $\begin{array}{l}\text { ip FLA-6 } \\
\text { ip PL-60 } \\
\text { Omm lor } \\
\text { riable dis } \\
\text { riable dis }\end{array}$ & $\begin{array}{l}11,6.0 \\
11,60.0 \\
\text { resist } \\
\text { laceme } \\
\text { laceme }\end{array}$ & $\begin{array}{l}\text { m long, } \\
\text { m long, } \\
\text { ce: } 119, \\
\text { transdu } \\
\text { transdu }\end{array}$ & $\begin{array}{l}\text { sistance } \\
\text { sistanc } \\
\pm 0,20 \Omega, \\
\text { rs) W1C } \\
\text { rs) W5( }\end{array}$ & $\begin{array}{l}120 \pm 0 \\
120 \pm 0\end{array}$ & & & & & & \\
\hline
\end{tabular}


Table2. Maximum force and deflection values obtained during the testing

\begin{tabular}{|c|c|c|c|c|c|c|c|c|}
\hline \multirow{3}{*}{ Beam } & \multirow{3}{*}{$\begin{array}{l}\text { Fmax } \\
{[\mathrm{kN}]}\end{array}$} & \multirow{3}{*}{$\begin{array}{l}\text { GiV1(max) } \\
\text { [mm] }\end{array}$} & \multirow{3}{*}{$\begin{array}{c}\text { GiV1 } \\
\text { (residual } \\
\text { strain) } \\
{[\mathrm{mm}]}\end{array}$} & \multicolumn{5}{|c|}{ Behaviour of elements at ultimate load } \\
\hline & & & & \multicolumn{2}{|c|}{ Concrete girder } & \multicolumn{2}{|c|}{ Timber girder } & \multirow{2}{*}{ Reinforcement } \\
\hline & & & & Compression zone & Tension zone & Compression zone & Tension zone & \\
\hline SG1 & 65,34 & 23,725 & 1,303 & \multirow{5}{*}{ 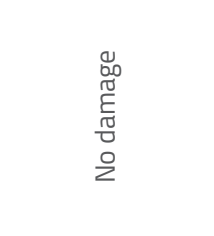 } & \multirow{5}{*}{$\begin{array}{l}\text { Cracks in } \\
\text { second third } \\
\text { of girder } \\
\text { span }\end{array}$} & \multirow{5}{*}{ 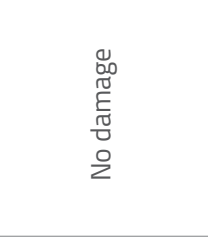 } & \multirow{5}{*}{$\begin{array}{c}\text { Brittle } \\
\text { fracture } \\
\text { occurs at the } \\
\text { edge fibres }\end{array}$} & \\
\hline SG2 & 70,22 & 25,456 & 2,534 & & & & & \\
\hline SG3 & 80,07 & 30,209 & 2,250 & & & & & \\
\hline SG4 & 90,18 & 32,378 & 2,456 & & & & & \\
\hline SG5 & 75,12 & 28,769 & 2,940 & & & & & \\
\hline PSG1 & 131,88 & 48,463 & I & \multirow{5}{*}{ 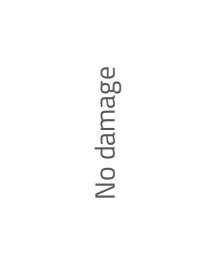 } & \multirow{5}{*}{$\begin{array}{l}\text { Cracks in } \\
\text { second third } \\
\text { of girder } \\
\text { span }\end{array}$} & \multirow{5}{*}{ 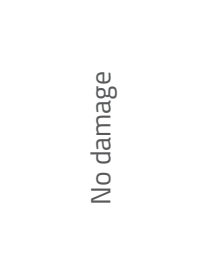 } & Contact* $^{*}$ & \multirow{5}{*}{ 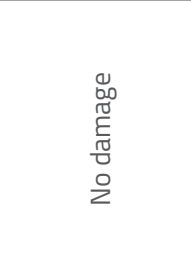 } \\
\hline PSG2 & 145,08 & 47,450 & 8,109 & & & & Contact $^{*}$ & \\
\hline PSG3 & 115,32 & 30,758 & 1,088 & & & & $\underset{* *}{\text { Brittle fracture }}$ & \\
\hline PSG4 & 126,72 & 36,334 & 1,831 & & & & Contact* $^{*}$ & \\
\hline PSG5 & 146,64 & 46,925 & 4,494 & & & & Contact $^{*}$ & \\
\hline
\end{tabular}

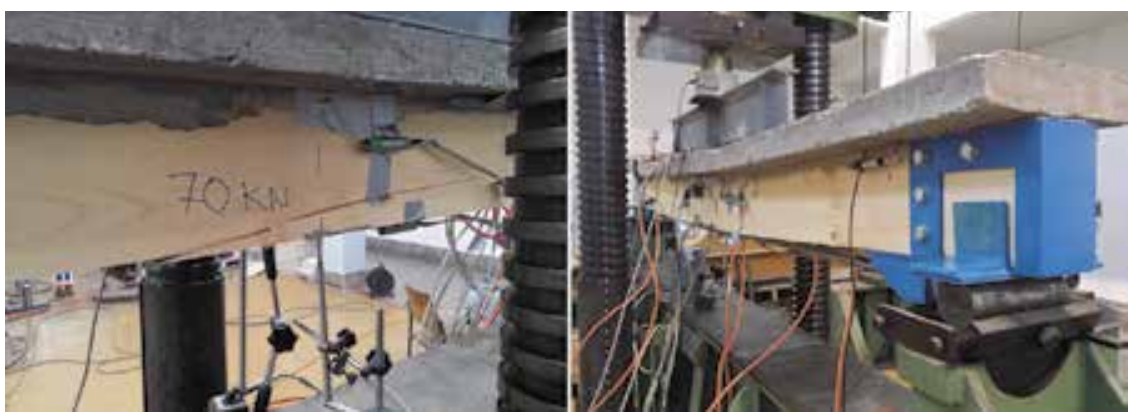

Figure 13. Tested girders: composite (SG2) and composite-prestressed (PSG1)

\section{Analysis of results}

The main objective of the research was to compare behaviour of composite girders without prestressing and with prestressing, when subjected to shortterm static load. The analysis of results presented in Table 2 and Diagram 1 reveals that overall characteristics of strengthened composite girders were improved considerably. First, the bearing capacity was increased significantly.

\section{Test results}

Typical deformations and damage to girders subjected to maximum stress are shown in Figure 13. Maximum force attained and the corresponding deformations (deflections and residual deformations) are presented in Table 2 where SG denotes composite girders and PSG composite-prestressed girders. The force - deflection ratio of tested composite and composite-prestressed girders is shown in Figure 14.

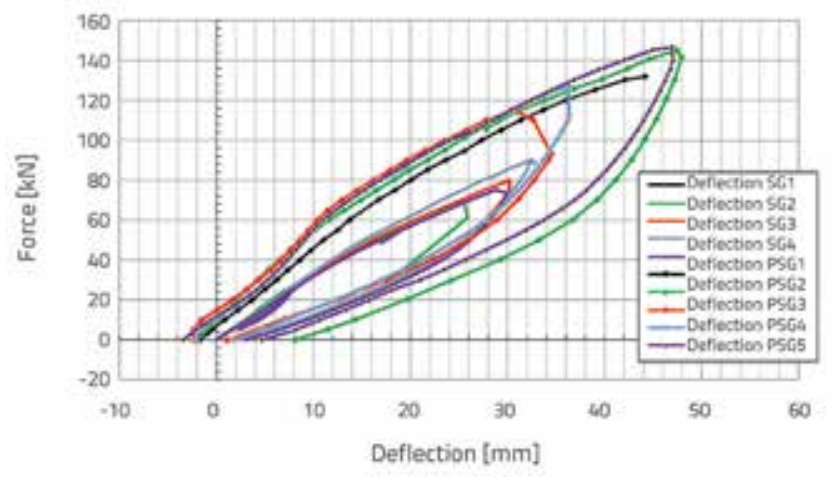

Figure 14. Force - deflection ratio of tested girders
An average value of maximum forces applied on tested girders amounts to about $76.0 \mathrm{kN}$ for composite girders and to about $133.0 \mathrm{kN}$ for composite-prestressed girders, which shows that the strengthening of about $75 \%$ was achieved. At that, the differences in deflection are just slightly above 1.0 $\mathrm{cm}$. Considering its simplicity and cost-effectiveness, it can be stated that good results can be achieved by this kind of strengthening. At maximum load, all composite beams suffered sudden failure of tensioned fibres of the timber girder, which was followed by a loud cracking noise. On the other hand, all strengthened beams (with the exception of one) did not fail, but rather the testing was stopped at the moment in which the bottom edge of the timber girder entered into contact with the tendon. Irregularities in wood (knot that changed the direction of fibres in critical cross section) caused somewhat earlier failure of beam PSG3. This means that the strengthened girders exhibit a highly ductile behaviour. This is further confirmed by another observation, i.e. by delayed occurrence of cracks in the concrete part of the girder. In addition, residual strains are small ( 2.0 to $4.0 \mathrm{~mm}$ ) thanks to influence of external reinforcement made of high-strength steel (yield limit: 620.0 MPa). 


\section{Conclusion}

The main objective of the research that is partly presented in this paper was to determine the composite-girder strengthening effect. The presented type of girder can appropriately be used in construction practice either for strengthening the existing or for the design of new girders. It should be noted that girder testing is limited to short-term load, with mechanical properties of materials, without rheological effects. Subsequent research should also cover the effects related to long-term load, including the effects of the surrounding environment (humidity, temperature, etc.). Special attention must be paid to the intensity of prestressing force in external reinforcement over time. The loss of prestressing force is the phenomenon that is present in all girders of this type, regardless of the material they are made of. In this paper, one prestressing variant is tested for rectilinear external reinforcement, in which case the system fully leans onto the wooden part of the girder. Girders in which anchoring would be in concrete part of the girder can also be designed but in that case the spreading of the reinforcement would be polygonal, with one or two deviators. Here, the girder uplift would be realised by means of deviating force in the deviator, which would cause compressive stress perpendicular to fibres in the timber girder. In subsequent research, it would be necessary to test various types of prestressing so as to determine, through comparison of results, which type has the best performance from the aspect of bearing capacity, and from the aspect of practical use. In addition, to enable practical use of the girders under study, it would bel necessary to simplify, based on experimental research, the calculation model used in this research by introducing relevant parameters.

\section{REFERENCES}

[1] Postulka, J.: Strengthening of wooden ceiling constructions, Reports of the Working Commissions, International Association for Bridge and Structural Engineering (IABSE), 46 (1983), pp. 441447.

[2] Yeoh, D.E.C.: Behaviour and Design of Timber-Concrete Composite Floor System, Ph.D. Thesis, University of Canterbury, Department of Civil and Natural Resources Engineering, New Zealand, 2010.

[3] Ceccotti, A.: Composite concrete-timber structures, Progress in Structural Engineering and Materials, 4 (2002), pp. 264-275.

[4] Dias, A.M.P.G., Jorge, L.F.C.: The effect of ductile connectors on the behaviour of timber-concrete composite beams, Engineering Structures, 33 (2011), pp. 3033-3042.

[5] Steinberg, E., Selle, R., Faust, T.: Connectors for timber-lightweight concrete composite structures, Journal of Structural Engineering, 129 (2003) 11, pp. 1538-1545.

[6] Ceccoti, A., Fragiacomo, M., Giordano, S.: Long-term and collapse tests on a timber-concrete composite beam with glued-in connection, Materials and Structures, 40 (2006), pp. 15-25.

[7] Lukaszewska, E.: Development of Prefabricated Timber-Concrete Composite Floors, Ph.D. Thesis, Luleå University of Tehnology, Department of Civil, Mining and Enviromental Engineering, Sweden, 2009.

[8] Gutkowski, R., Brown, K., Shigidi, A., Natterer, J.: Laboratory tests of composite wood-concrete beams, Constraction and Building Materials, 22 (2008) 6, pp. 1059-1066.

[9] Stevanović, B.: Analysis of Composite Timber-Concrete Structures, Doctoral thesis, Faculty of Civil Engineering, Belgrade, 2003.

[10] Möhler, K.: Über das Tragverhalten von Biergerträgern und Druckstäben mit zusammengezetztgen Querschnitten und nachgiebigen Verbindungsmitteln, Habilitation, Technische Universität Karlsruhe, Germany, 1956.

[11] Moar, F.: Prefabricated timber-concrete composite system, Master teza, Lunds Universitet, 2012

[12] EN 1995-1-1, Design of timber structures, Part 1-1: General Common rules and rules for buildings, European Committee for Standardization, Brussels, Belgium, 2004.

[13] Ceccotti, A.: Timber-Concrete Composite Structures. In: Blass HJ et al. (ed) Timber Engineering, Step 2, $19951^{\text {st }}$ edn. Centrum Hout, The Netherlands.

[14] Čizmar, D., Vrančić, M.: Analysis of timber-concrete composite girders, GRADEVINAR, 68 (2016) 7, pp. 559-570, doi: https://doi. org/10.14256/JCE.1452.2015

[15] Tajnik, M., Dobrila, P., Premrov, M.: Analysis of composite T beam composed of timber, concrete and carbon strip, WSEAS TRANSACTIONS on APPLIED and THEORETICAL MECHANICS, 2 (2007) 9, pp. 177-186

[16] Deam, B.L., Fragiacomo, M., Gross, L.S.: Experimental Behavior of Prestressed LVL-Concrete Composite Beams, Journal of Structural Engineering, 134 (2008), pp 801-809. 